\title{
Abnormal incisor growth in Eurasian beaver
}

\author{
Frank ROSELL and Nils B. KILE
}

\begin{abstract}
Rosell F. and Kile N. B. 1998. Abnormal incisor growth in Eurasian beaver. Acta Theriologica 43: 329-332.

An abnormally long incisor of an adult Eurasian beaver Castor fiber Linnaeus, 1758 is reported. The animal weighed about $20 \mathrm{~kg}$ and was in good condition when shot at 3 years of age. The tooth had grown at an angle in towards the beaver's left eye. Assuming the animal to be 35 months old and total tooth length to be $13.5 \mathrm{~cm}$, then growth rate would have been $0.39 \mathrm{~cm}$ per month. This report indicates that beaver can survive despite abnormal growth of one incisor.
\end{abstract}

Telemark College, Department of Environmental Sciences, N-3800 Bø, Norway, e-mail: Frank.Rosell@hit.no

Key words: Castor fiber, abnormal incisor, hypertropy, Norway

We report here, apparently for the first time, on an abnormally long incisor in free-living Eurasian beaver Castor fiber Linnaeus, 1758. On 30 April, 1993, a 20 $\mathrm{kg}$ beaver of unknown sex, and age 3 years (Hartman 1992) was shot at Bjoraavika, Southeast Norway $\left(58^{\circ} 33^{\prime} \mathrm{N}, 7^{\circ} 48^{\prime} \mathrm{E}\right)$. The beaver sat on shore gnawing on a birch Betula pubescens twig when shot. It smacked its lips and made considerably more noise than usual while eating.

The incisor of the lower left jaw was longer than usual (Fig. 1). The point of exit from the mandible was slightly to the right (viewed from the front) of that which is normal. The incisor terminated in a point and not in a sharp edge as in a normal functioning incisor (eg Osborn 1969) (Fig. 1). The incisor was $13.5 \mathrm{~cm}$ long measured from estimated gum level, and the outer $8 \mathrm{~cm}$ was white and without the characteristic orange enamel (eg Allred 1986) (Fig. 1). The bone structure around the incisor at the point of exit from the mandible was unusually "open", and the tooth had grown at an angle in towards the beaver's left eye.

The hunter who shot the beaver reported that the three other incisors appeared normal, and that the animal was in good condition. The beaver belonged to a family group, and being an adult, may have taken part in reproduction.

Beaver incisors are open-rooted, large, and grow continually. The outside surfaces are covered by hard, orange enamel and the inside with white dentin which, because it is softer, is worn down more rapidly than the enamel (eg Novak 1987). This results in a chisel-sharp cutting edge (Osborn 1969). Proper function 


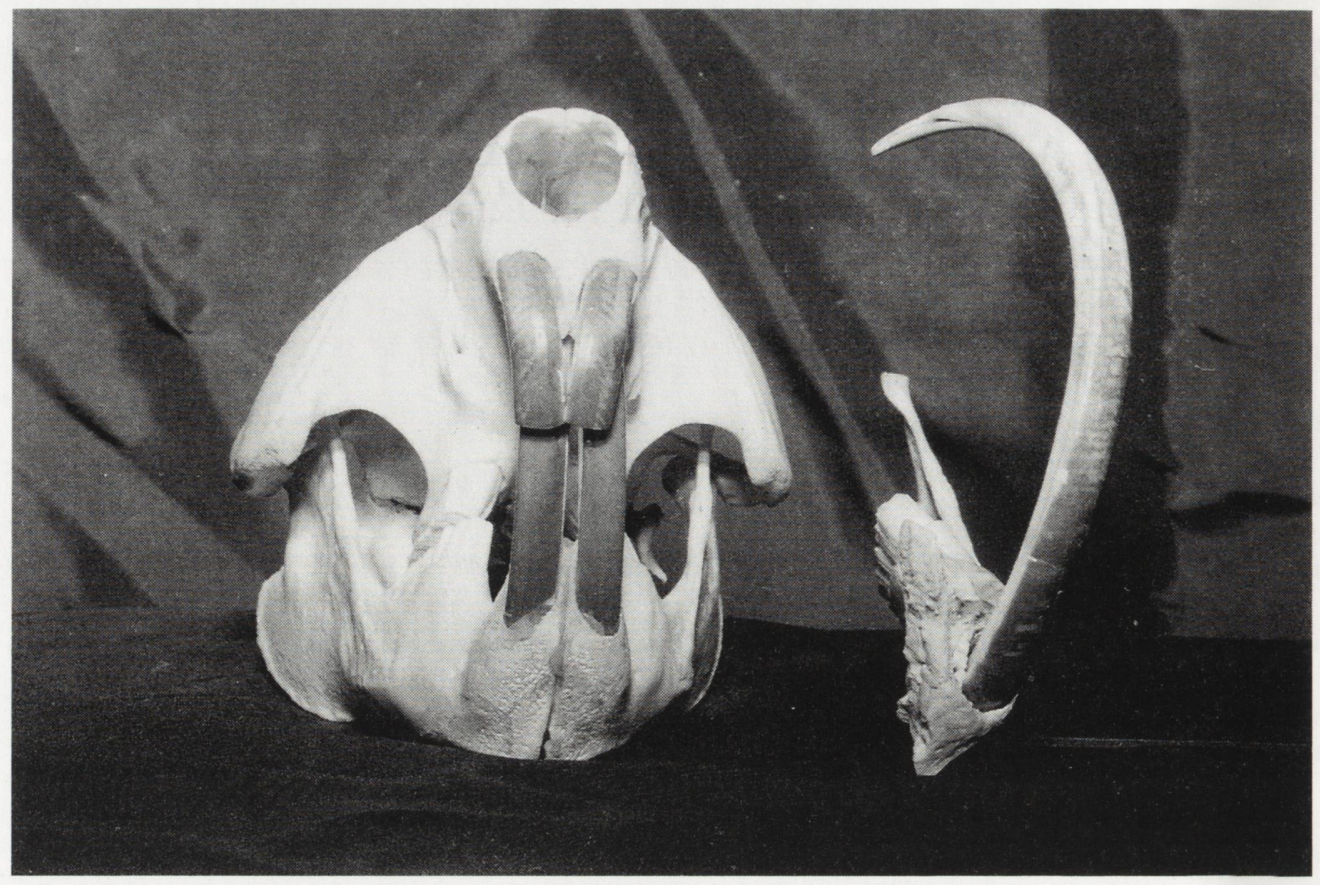

Fig. 1. The abnormal length of the beaver incisor in the lower left jaw viewed together with the skull of a normal 1.5-year-old. The angle of exit from the mandible is slightly to the right (when viewed from the front) of that which is normal. The tooth is also pointed, suggesting either a birth defect, or a damage to the tooth and jaw shortly after birth.

throughout life requires that the beaver's incisors must be worn down regularly (Żurowski and Krzywiński 1974).

Tooth sharpening occurs by grinding the upper and lower incisors against each other with quick jaw movements (Osborn 1969, Wilsson 1971). This process begins at about 1.5 months age (Leighton 1932, Wilsson 1971, Patenaude 1984). The beaver's incisors are important in a number of different capacities including feeding, gnawing and cutting, grooming, transport of young, displacement activity, intraspecific threats and weapons (Wilkinson 1962, Wilsson 1971, Patenaude 1983, Valeur 1988). Thus, considering the multiple function of the incisors in beaver, it is amazing that this individual managed to survive 3 years with no apparent detrimental effects.

Beaver incisors grow persistently so that the loss of any such tooth is followed by the unrestrained growth of its former antagonist (Cave 1984). Only a single detailed example of such incisor tooth loss has been reported for the North American beaver C. canadensis Kuhl, 1820 (Cave 1984), however this is also reported by Morgan (1868) and Allred (1986). In Cave's specimen, the loss of a maxillary incisor had permitted its remaining antagonist to attain extraordinary 
proportions. The right mandibular incisor had grown successively upwards, backwards and downwards so as to form an almost completely circular structure (see fig. 2 in Cave 1984). Its free extremity had pierced the cheek-tissues to descend upon the medial aspect of the mandibular ascending ramus and to terminate immediately behind the last molar tooth. Such incisor hypertrophy must obviously have inflicted much damage upon the local soft parts and have considerably impaired mandibular activity. Nevertheless, the animal had survived to full maturity.

Żurowski and Krzywiński (1974) also described cases of hypertrophy of the incisors, hypertrophy combined with curvature of the teeth into the interior of the mouth, and oblique wear of the incisors in captive Eurasian beavers. Abnormal wear of the incisors reduced the animals powers of performance, causing death in some cases. Ramashov (1969) (cited in Żurowski and Krzywiński 1974) stated that a defective bite was often encountered in both free-living and captive beavers. Żurowski and Krzywiński (1974) stated that both lower and upper incisors were capable of excessive growth, and as a rule the loss of one of the incisors caused excessive growth of the opposite one. In a free-living condition this defect probably causes the animal's death. Of 500 beaver craniums examined in Kristiansand Museum, Norway, none had an abnormally long incisor (P. Valeur, pers. comm.).

Beaver are born with pointed incisors (Dzięciołowski 1996). This fact, plus the evidence of a slightly deformed mandible, suggest that the malady we describe resulted either from a birth defect, or from damage to the tooth and jaw shortly after birth. The tooth appeared to have grown to its present length without ever having functioned properly. Assuming this to be the case, then the length of this abnormal incisor might be used to determine tooth growth rate in beaver. Assuming the animal to be 35 months old and total tooth length to be $13.5 \mathrm{~cm}$, then growth rate would have been $0.39 \mathrm{~cm}$ per month. Both maxillary incisors may have been maintained at normal length, in part, by gnawing movements against the single functioning manibular incisor, this report indicates that beaver can survive despite abnormal growth of one incisor.

Acknowledgments: We thank F. Bergan and H. Parker for reviewing the manuscript, L. Audunson and I. M. Bjelland for taking the X-ray pictures for age determination, H. Parker for taking the picture, and A. Czech for translation of the Polish article.

\section{References}

Allred M. 1986. Beaver behavior: architect of fame \& bane! Happy Camp, California: Naturegraph: $1-110$.

Cave A. J. E. 1984. Dentitional anomalies in the beaver and some other mammals. [In: Investigations on beavers II. G. Pilleri, ed]. Institute of brain anatomy. University of Berne, Berne: 145-151.

Dzięciołowski R. 1996. [Beaver]. Wydawnictwo SGGW, Warszawa: 1-124. [In Polish]

Hartman G. 1992. Age determination of live beaver by dental x-ray. Wildlife Society Bulletin 20: $216-220$. 
Leighton A. H. 1932. Notes on the beaver's individuality and mental characteristics. Journal of Mammalogy 12: 117-126.

Macdonald D. W., Tattersall F. H., Brown E. D. and Balharry D. 1995. Reintroducing the European beaver to Britain: nostalgic meddling or restoring biodiversity? Mammal Review 25: 161-200.

Morgan L. H. 1868. The American beaver and his works. J. D. Lippincott and Company. Philadelphia: $1-330$.

Novak M. 1987. Beaver. [In: Wild furbearer management and conservation in North America, Ontario. M. Novak, J. A. Baker, M. E. Obbard and B. Malloch, eds]. Ontario Ministry of Natural Resources: 283-312.

Osborn J. W. 1969. Dentine hardness and incisor wear in the beaver (Castor fiber). Acta Anatomica 72: $123-132$.

Patenaude F. 1983. Care of the young in a family of wild beavers, Castor canadensis. Acta Zoologica Fennica 174: 121-122.

Patenaude F. 1984. The ontogeny of behavior of free-living beavers (Castor canadensis). Zeitschrift für Tierpsychologie 66: 33-44.

Patenaude F. and Bovet J. 1984. Self-grooming and social grooming in the North American beaver, Castor canadensis. Canadian Journal of Zoology 62: 1872-1878.

Schadle A. R. 1956. The American beaver. Animal Kingdom. 59-61.

Valeur P. 1988. [Territorial behavior as factor in regulation of populations in beaver]. Fauna 41: 20-34. [In Norwegian with English summary]

Walro J. M. 1980. Castor and anal glands of North American beaver (Castor canadensis): histology and communicatory) functions of secretions. Ph D thesis, Ohio University, Athens.

Wilkinson P. M. 1962. A life history study of the beaver in east-central Alabama. M Sc thesis, Auburn University, Auburn, Alabama.

Wilsson L. 1971. Observations and experiments on the ethology of the European beaver (Castor fiber L). Viltrevy 8: 115-266.

Żurowski, W. and Krzywiński A. 1974. Anomalies in the wear of incisors in the European beaver. Acta Theriologica 19: 367-378.

Received 28 April 1997, accepted 2 January 1998. 